\title{
UTILIZATION OF RECYCLED COAL MINING WASTE FOR ROAD FOUNDATION LAYERS IN VIETNAM
}

\author{
*Tong Ton Kien ${ }^{1}$ and Pham Thi Vinh Lanh ${ }^{2}$ \\ ${ }^{1}$ Building materials faculty, National University of Civil Engineering, Hanoi, Vietnam; ${ }^{2}$ Construction faculty, \\ College of Technical and Construction No1, Hanoi, Vietnam; \\ *Corresponding Author, Received: 09 June 2021, Revised: 05 Oct. 2021, Accepted: 17 Oct. 2021
}

\begin{abstract}
Road foundation is commonly used crushed aggregates from natural stone or gravel, natural sand, or soil with natural gravel. However, nowadays the sources of natural materials have been increasingly exhausted. This promotes the search and utilization of other materials to replace these natural materials for road construction projects. Meanwhile, the total volume of coal mining waste (CMW) released from coal exploitation in Vietnam has reached 460 million $\mathrm{m}^{3} /$ year. This waste is mainly the disposal of soil-rocky waste mountains at coal mining sites, which leads to waste natural resources and landfill areas. Therefore, this research on using CMW as recycled aggregates to replace natural aggregates. It is not only to minimize the consumption of natural resources and solve the shortage of raw materials for road construction but also to reduce the mammoth volume of CMW at coal mining fields. This paper focuses on compaction characteristics and California Bearing Ratio (CBR) of CMW recycled aggregates (RAs) for the subgrade and foundation layers application. The results show that the maximum dry density (MDD) of the recycled sand $\left(D_{\max }=4.75 \mathrm{~mm}\right)$ ranges from $1.695-1.912 \mathrm{~g} / \mathrm{cm}^{3}$, the optimum moisture content (OMC) of 15.1-18.1\%, and the CBR value reaches $33-44 \%$. As for graded macadam $\left(D_{\max }=25 \mathrm{~mm}\right)$ has the $\mathrm{MDD}=2.091-2.307 \mathrm{~g} / \mathrm{cm}^{3} ; \mathrm{OMC}=5.1-6.7 \%$ and $\mathrm{CBR}=89-123 \%$. These results proved that it is possible to use CMW as recycled sand to replace natural sand and macadam aggregate type II $\mathrm{D}_{\max }=25 \mathrm{~mm}$ as bases and subbases pavement for sub-surface foundation layers in Vietnam.
\end{abstract}

Keywords: Coal Mining Waste (CMW), California Bearing Ratio (CBR), Road Bases and Subbases Materials, Macadam Aggregates, Recycled Aggregates (RAs)

\section{INTRODUCTION}

The development of an industry in the world and developing countries particularly entails many negative impacts on the environment; especially the large amounts of industrial waste generated annually have not been thoroughly treated. In 2016, the total waste generated in the 28- European countries by all economic activities and households amounted to 2261 million tonnes, of which more than $74 \%$ of industrial waste accounted for 1673 million tons, in particular, the only waste from mining and quarrying is 624 million tonnes [1]. In the US, the amount of hazardous waste from domestic industries increased from 265 million tons in 1990, to 29.1 billion tons in 2015 [2]. In China, the amount of coal mining waste (CMW) was 315 million tons for underground coal mining [3]. Therefore, the recycling of industrial wastes as construction materials has been interested in many countries to minimize the environmental impacts caused by the landfill area [4], as well as replacing the natural aggregates for the construction industry [3, 5-12].

Indranratna et. al. [6] has examined the compatibility of coal tailings by both the standard and modified Proctor compaction methods. The maximum dry density (MDD) and the optimum moisture content (OMC) for standard compaction are $13.7 \mathrm{kN} / \mathrm{m}^{3}$ $\left(\sim 1397 \mathrm{~kg} / \mathrm{m}^{3}\right)$ and $14 \%$, respectively. Meanwhile, the MDD for modified Proctor compaction is about $15.5 \mathrm{kN} / \mathrm{m}^{3}\left(\sim 1581 \mathrm{~kg} / \mathrm{m}^{3}\right)$, with an OMC of $12 \%$. CBR values of the specimens compacted at the OMC of $12 \%$ using the modified Proctor is $90 \%$, which is much higher than that values achieved for standard Proctor specimens at similar moisture contents (only about 20\%). H. Jang [9] also researched the characterization of seven coal-mine wastes in solid backfill mining in China. The results show that the MDD varied within the range 1.636$1.917 \mathrm{~g} / \mathrm{cm}^{3}$, while OMC ranged from 6.64 to $11.03 \%$. This result is similar to the study of Kafakis [11] when using nine types of US mine waste, MDD and OMC are in the range of $1.66-2.00 \mathrm{~g} / \mathrm{cm}^{3}$ and $7.2-11.4 \%$, respectively. These results are much lower than the MDD, or CBR of natural aggregates are usually $1.9-2.5 \mathrm{~g} / \mathrm{cm}^{3}$ and $25-180 \%$. These properties mainly depend on the particle size $\left(D_{\max }\right)$, fines content, and type of aggregates [12]. However, the high MDD and CBR values will not be required for most pavements. Therefore, we need to evaluate the quality of each specific material before choosing for each type of pavements and roads either as base or subbase to maximum utilization of local material resources.

In Vietnam in recent years, the construction industry has been developing strongly to meet the needs of 
infrastructure construction for socio-economic development. Therefore, the demand for construction materials is also increasing sharply. In 2020 the sand for construction aggregate and levelling up to about $120-130$ million $\mathrm{m}^{3}$ /year and 525-575 million $\mathrm{m}^{3} /$ year respectively $[13,14]$. However, the total capacity of exploiting natural sand for construction sand is only approximately 29 million $\mathrm{m}^{3}$ (equal to $24.2 \%$ of the demand), and the sand as filling materials is only about 4.58 million tons (just equal to $1.5 \%$ of the demand) [14]. Therefore, the natural sand price in many localities is very high, the mining sand is illegal frequently. So that the Government has had to take many remedies such as strengthening research to use other materials (manufactured sand, utilizing industrial waste/sludge materials, construction and demolition wastes, fly ash, slags, etc.) to reduce the use of natural aggregates for levelling construction [14, 15].

Meanwhile, a huge amount of industrial solid waste generated is increasing rapidly up to $15-20 \%$ year [16]. Especially, the coal mining industry (CMW) accounts for the highest. CMW includes stone, soils and other impurities lying on the mine surface, that are removed during coal exploitation at the mine sites. In Vietnam, the coefficient of excavated soilstone in open-cast mines (stripping ratio) is very high, ranging around $3-13 \mathrm{~m}^{3} /$ ton of coal product. According to the coal mining plan until 2025, the stripping ratio is from $5.9-10.2 \mathrm{~m}^{3} /$ ton of coal. The total amount of CMW released into the environment is 4.6 billion $\mathrm{m}^{3} /$ year [16]. In only 2016, the CMW was generated 310 million $\mathrm{m}^{3}$ [17]. This waste is used only very little as backfill mining, most of the remaining made up of waste mountains near the mining area (Fig. 1). Particularly for 10 coal mines in Quang Ninh province of Vietnam, the volume of CMW between 2015-2019 has stored up to 750 million $\mathrm{m}^{3}$, an average continues to generate an additional 250-300 million $\mathrm{m}^{3} /$ year [15]. The main components of CMW are $56-68 \%$ of sandstone; 32$44 \%$ of siltstone; $5-12 \%$ soils/ clay and other impurities [15]. So that CMW is a by-product of coal mining and were classified as inert or nonhazardous waste [28, 29]. However, until now there have been no researches and applications of CMW in Vietnam [15, 17]. Therefore, these wastes can be completely produced as recycled aggregates (RAs) to replace the natural aggregates in construction projects. This is a sustainable solution that not only solves the storage and negative impacts on the environment of the mining areas but also contributes to saving natural resources, as well as solving the shortage of road construction materials in Vietnam. This paper presents the investigated feasibility of RAs produced from CMWs as road foundation materials. The results on particle compositions, compaction characteristics, California bearing ratio (CBR), and other physical-technical properties have been analyzed, compared to the national standards.

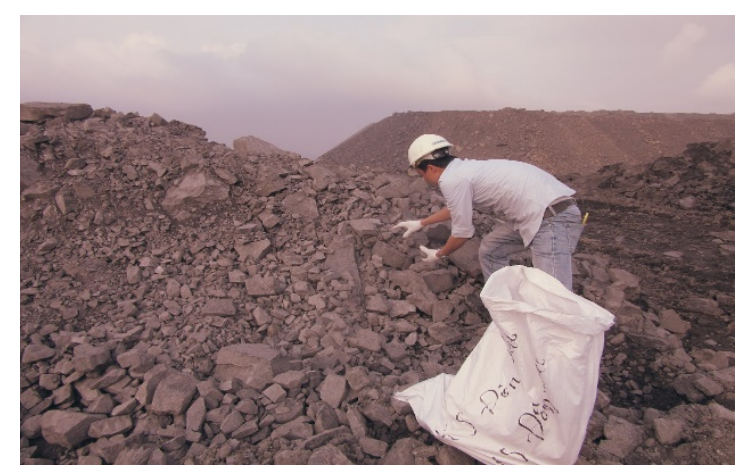

Fig.1 Coal mining waste at the disposal area

\section{MATERIALS AND TEST METHODS}

\subsection{CMW Samples}

CMW samples (M1-M10) are composed of sandstone and soil mixture, which were collected at 10 disposal sites of coal mining exploitation in Quang Ninh Province, Vietnam (Fig. 1). These CMWs are crushed and sieved by a sand production line with a capacity of 150 tonnes/hour [15]. The major product is crushed sand. Which is used to replace natural sand for mortar and concrete production. In this paper, we only use two byproducts which are recycled coarse aggregates with $\mathrm{D}_{\max }=25 \mathrm{~mm}$ (RCAs) as unbound roadbed materials and recycled fine aggregates with $D_{\max }=4.75 \mathrm{~mm}$ (RFAs) as levelling sand in the road subgrade layer. The RCAs were obtained right after the jaw crusher and sieved through a $37.5 \mathrm{~mm}$ size. The RFAs were fine sand collected after depositing washed water of the sand washing system.

The mineralogical information and elemental compositions of the sandstone in CMW samples were determined by X-ray diffraction and X-ray fluorescence analyzers. The diffraction patterns were illustrated in Fig. 2. The mineral and chemical composition of the different sandstones was shown in Table 1 and Table 2.

From the mineral composition results of the original sandstone samples in 10 CMWs (Fig. 2 and Table 1), it was found that these all original rock samples appeared Quartz-SiO 2 (Q). The mineral Picromerite$\mathrm{K}_{2} \mathrm{Mg}\left(\mathrm{SO}_{4}\right)_{2} \cdot 6 \mathrm{H}_{2} \mathrm{O}(\mathrm{Pi})$ and the mineral Muscovite$\mathrm{KAl}_{3} \mathrm{Si}_{3} \mathrm{O}_{10}(\mathrm{OH})_{2}(\mathrm{M})$ appearing in most of the rock samples. Potassium Iron Hydrogen Phosphate$\mathrm{KFe}_{2}\left(\mathrm{H}_{2} \mathrm{P}_{3} \mathrm{O}_{10}\right)\left(\mathrm{P}_{4} \mathrm{O}_{12}\right)$ (Po) mineral only appear in M3, M6, and Nacrite- $\mathrm{Al}_{2} \mathrm{Si}_{2} \mathrm{O}_{5}(\mathrm{OH})_{4}(\mathrm{~N})$ mineral only appears in M2, M10 mines.

As shown in Table 2, the main chemical constituents of CMW samples were $\mathrm{SiO}_{2}, \mathrm{Al}_{2} \mathrm{O}_{3}, \mathrm{Fe}_{2} \mathrm{O}_{3}, \mathrm{~K} 2 \mathrm{O}$, and $\mathrm{TiO}_{2}$ with other trace components also present. $\mathrm{SiO}_{2}$ was found to be the dominant chemical constituent (75-93\%). The higher $\mathrm{SiO}_{2}$ content of 
CMW represents the strength and abrasiveness increase [11]. However, the presence of $\mathrm{Al}_{2} \mathrm{O}_{3}, \mathrm{~K}_{2} \mathrm{O}$, and other metal oxides may result in particle breakdown upon exposure to moisture, thus decreasing the overall strength of waste rock materials.

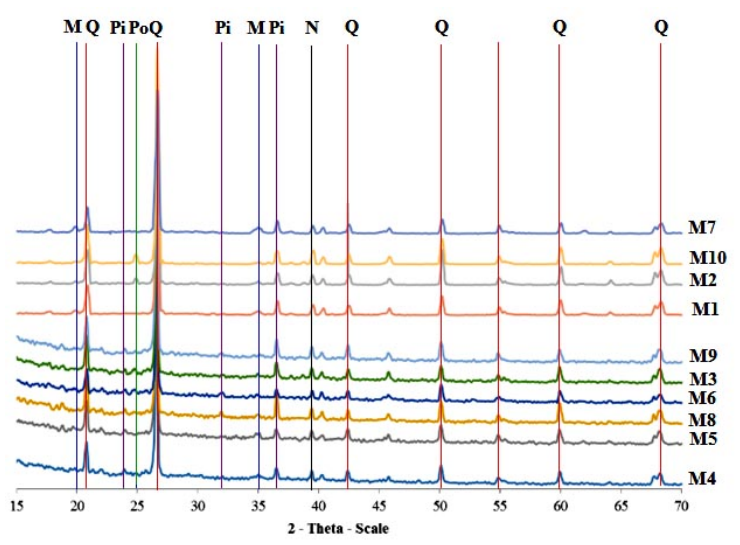

Fig.2 XRD pattern of the original sandstones

Table 1 The mineral composition of the different sandstones

\begin{tabular}{|c|c|c|}
\hline $\begin{array}{l}\text { Samp. } \\
\text { code }\end{array}$ & $\begin{array}{l}\text { Name of } \\
\text { mine }\end{array}$ & Mineral composition \\
\hline M1 & Ha Tu & Quartz-alpha (Q), Muscovite \\
\hline M2 & Hon Gai & $\begin{array}{l}\text { Quartz-alpha, Muscovite (M), } \\
\text { Nacrite (N) }\end{array}$ \\
\hline M3 & $\begin{array}{l}\text { Khoang san } \\
\text { Dong Bac }\end{array}$ & $\begin{array}{ll}\text { Quartz-alpha, Potassium } & \text { Iron } \\
\text { Hydrogen Phosphate } & \text { (Po), } \\
\text { Picromerite (Pi) } & \end{array}$ \\
\hline M4 & Cao Son & $\begin{array}{l}\text { Quartz-alpha, } \\
\text { Muscovite }\end{array}$ \\
\hline M5 & Coc Sau & $\begin{array}{l}\text { Quartz-alpha, } \\
\text { Muscovite }\end{array}$ \\
\hline M6 & Deo Nai & $\begin{array}{lr}\text { Quartz-alpha, Potassium Iron } \\
\text { Hydrogen } \\
\text { Picromerite }\end{array}$ \\
\hline M7 & $\begin{array}{l}\text { Mong } \\
\text { Duong }\end{array}$ & Quartz-alpha, Picromerite \\
\hline M8 & $\begin{array}{l}\text { Tay Nam Da } \\
\text { Mai }\end{array}$ & Quartz-alpha, Picromerite \\
\hline M9 & Nui Beo & Quartz-alpha, Muscovite \\
\hline M10 & Khe Sim & $\begin{array}{l}\text { Quartz-alpha, } \\
\text { Nacrite }\end{array}$ \\
\hline
\end{tabular}

The quality of the original sandstone types were assessed by their density and compressive strength of the representative samples from the CMWs mixture. The tested procedure was carried out according to TCVN 7572-2: 2006 [20]. The results are shown in Fig. 3.

It is clear that the compressive strength of the dry specimens varies greatly from 30.1-83.0 $\mathrm{MPa}$, and that of the saturated ones varies from 25.3-68.4 $\mathrm{MPa}$; this leads to the softening coefficient of parent stones fluctuating in a wide range of 0.71-0.98. The dry density of the specimens also varies from 2368 to $2938 \mathrm{~kg} / \mathrm{m}^{3}$. This proves that the degree of weathering and structural characteristics of sandstone samples varies greatly [15]. According to TCVN 8859: 2011 [21], the original rocks used for manufacturing graded aggregate bases and subbases pavement must have a compressive strength of at least $60 \mathrm{MPa}$ if used for the upper foundation layer and above $40 \mathrm{MPa}$ if used for the lower foundation. Therefore, M1 and M9 samples are not suitable for graded aggregate bases and subbases Pavement, but still suitable as filling materials to replace the soil or natural sand in the road foundation according to TCVN 8857: 2011 [20].

Table 2 The main chemical composition of the different sandstones

\begin{tabular}{ccccccc}
\hline $\begin{array}{c}\text { Samp. } \\
\text { code }\end{array}$ & $\mathrm{SiO}_{2}$ & $\mathrm{Al}_{2} \mathrm{O}_{3}$ & $\mathrm{~K}_{2} \mathrm{O}$ & $\mathrm{Fe}_{2} \mathrm{O}_{3}$ & $\mathrm{TiO}_{2}$ & Others \\
\hline M1 & 89.55 & 6.32 & 3.58 & 0.31 & 0.25 & 0.00 \\
M2 & 89.20 & 6.59 & 2.87 & 1.06 & 0.27 & 0.00 \\
M3 & 77.11 & 14.47 & 3.89 & 3.96 & 0.47 & 0.10 \\
M4 & 81.56 & 11.95 & 5.32 & 0.79 & 0.35 & 0.03 \\
M5 & 74.74 & 16.01 & 7.68 & 1.17 & 0.37 & 0.03 \\
M6 & 77.40 & 11.84 & 4.68 & 5.31 & 0.61 & 0.16 \\
M7 & 83.14 & 9.58 & 3.98 & 2.61 & 0.31 & 0.38 \\
M8 & 82.35 & 10.09 & 3.61 & 3.71 & 0.20 & 0.05 \\
M9 & 83.01 & 10.45 & 5.83 & 0.29 & 0.42 & 0.00 \\
M10 & 92.87 & 5.09 & 1.39 & 0.49 & 0.15 & 0.00 \\
\hline
\end{tabular}

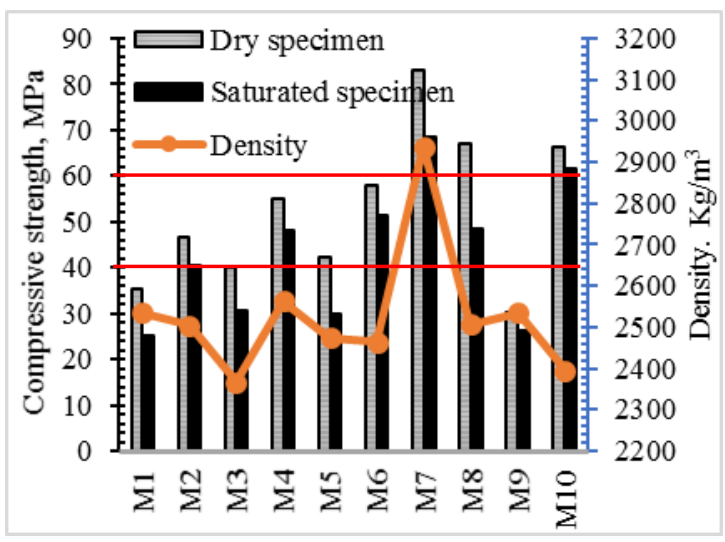

Fig.3 Density and compressive strength of the original sandstone rocks

\subsection{Experiment Methods}

In order to use RCAs as a base and subbase foundation layers in the road structure, the technical properties are evaluated as required by TCVN 8859: 
2011. For RFAs will be used to replace the natural sand and/ or soil for subgrade and backfill layers in the road, the properties were evaluated as required by TCVN 8857: 2011. All the technical properties were determined by the methods of Vietnam national standards (TCVN). These standards also conform to the ASTM and AASHTO standards respectively.

The particle size distribution analysis of the RCAs was performed according to TCVN 7572-2: 2006 [20], and that of RFAs was done by TCVN 4198: 2014 [23] and ASTM D6913/6913M [24].

The Optimum Moisture Content (OMC) and Maximum Dry Density (MDD) of each CMW sample were tested according to the procedures specified in the standards AASHTO T99 (I-A standard compaction method) [25] and T180 (II-D modified Proctor method) [26] respectively. A 2.5 $\mathrm{kg}$ hammer with a $305 \mathrm{~mm}$ drop was used in the standard compaction test and a hammer weighing $4.5 \mathrm{~kg}$ and a drop height of $450 \mathrm{~mm}$ was used in the modified Proctor method.

CBR value is the important property for assessing the quality of road foundation materials; it is also used to evaluate the strength of motorway structures and airport pavements in some design methods using strength parameters according to CBR. In this study, the CBR test was performed in the laboratory according to the standard AASHTO T193 [27] (Fig. 4).

The Liquid Limit $\left(\mathrm{W}_{\mathrm{L}}\right)$ and plasticity index $\left(\mathrm{I}_{\mathrm{P}}\right)$ of RAs were determined according to the standard methods TCVN 4197: 2012 [28], and AASHTO T90 [29].

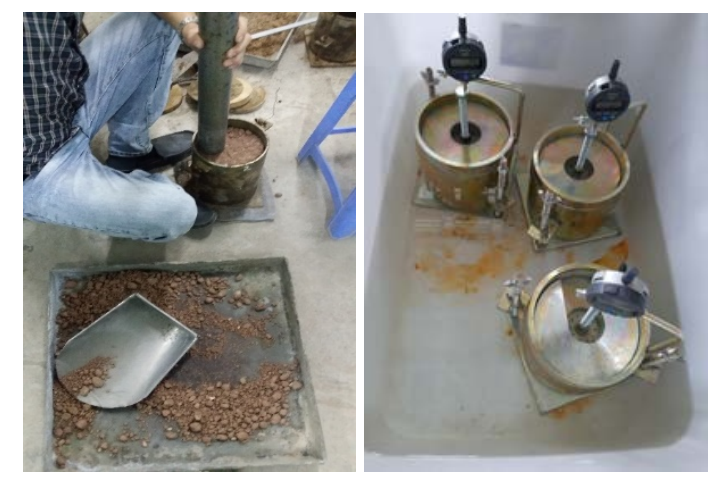

Fig.4 Preparing samples for CBR test

\section{RESULTS AND DISCUSSION}

\subsection{Particle Size Distribution}

In theory, backfill materials containing well-graded particles should offer increased displacement resistance relative to the one characterized by a uniform particle-size gradation, if all other factors are equal [11]. Thus, particle-size gradation should be strictly controlled in field applications and may be improved via the adjustment of particle-size proportions. The gradation of the experimental RAs is shown in Fig. 5.

a)

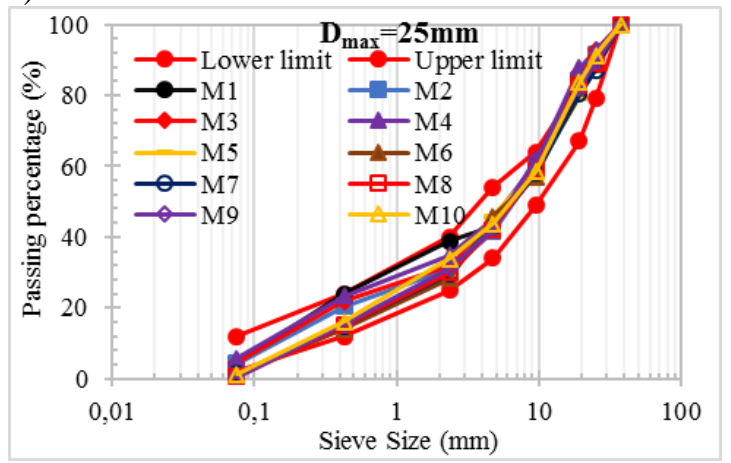

b)

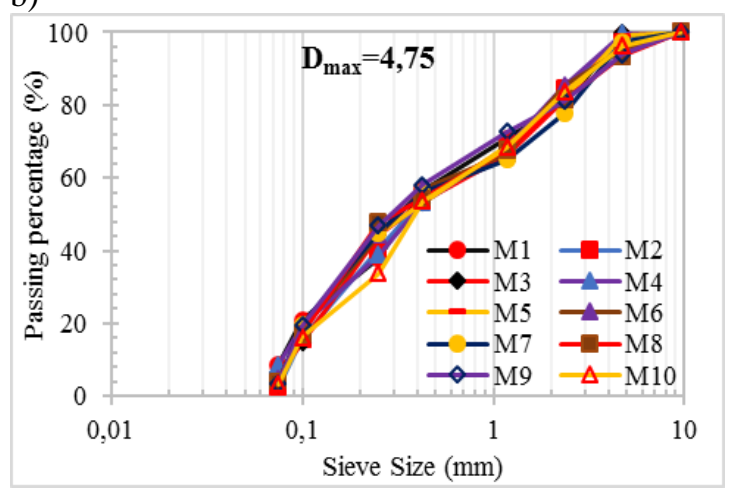

Fig.5 Particle size distributions of RCAs (a) and RFAs (b).

The results show that there is almost no significant difference in the particle composition for both types of RAs. Based on sieve analyses, RCAs were characterized by a wide grain-size range, the main difference in the particle size range from 2.36 to $0.075 \mathrm{~mm}$ is the sand particle size in the graded mixture (Fig. 5a); while the particle content from 2.36 to $37.5 \mathrm{~mm}$ is quite uniform and meets the requirements of TCVN 8859: 2011 [21]. This is due to the change in the proportion of soil materials and sandstone of different CMW at different coal mines. For RFAs, the particle size distribution of the samples did not differ significantly (Fig. 5b). This is because the RFAs are the waste sand after CMWs undergo hammer crushing, verticle shaft impact crushing, and washing crushed sand; so that the stone particles were broken more evenly. There are major differences in the granular size from 0.25 to $0.075 \mathrm{~mm}$ because this grade mainly depends on the ratio of soil and sandstone in CMWs. With this particle distribution, RFAs need to be mixed with natural stone aggregate to create the grade 
foundations type A, B, C, D meeting the requirements of TCVN 8857: 2011 [22].

\subsection{Compaction Characteristics}

Compaction curves that were obtained from the tests are displayed in Fig. 6 and the results of OMC and MDD of RAs are illustrated in Table 3 and Table 4. It can be seen that RCA M3 and M4 have quite large variations in water content compared to other samples (Fig. 6a). This is because the fine particle content $<0.075 \mathrm{~mm}$ are quite high as $4.6 \%$ and $5.7 \%$ respectively, which contains mainly clay or siltstone particles with high water absorption. Moreover, the MDD of RCAs is $20-23 \%$ higher and the optimum moisture content is about 2.7-3.5 times higher than these properties of RFAs. The MDD and OMC of RCAs ranged from $2.091-2.307 \mathrm{~g} / \mathrm{cm}^{3}$ and 5.1-6.7\% respectively; while these values of RFAs are wide range from $1.695-1.912 \mathrm{~g} / \mathrm{cm}^{3}$ and 14.2$18.1 \%$. This explains that the RFAs composition contains a large amount of clay, silt clay with low specific density and higher water absorption; while RCAs mainly consist of sandstones and sand with higher specific density and lower water absorption. It is clear that OMC typically exhibits a significant influence on compaction MDD and in-field applications, so the degree of compaction of RCAs must be strictly controlled to achieve an appropriate fill than that of RFAs.
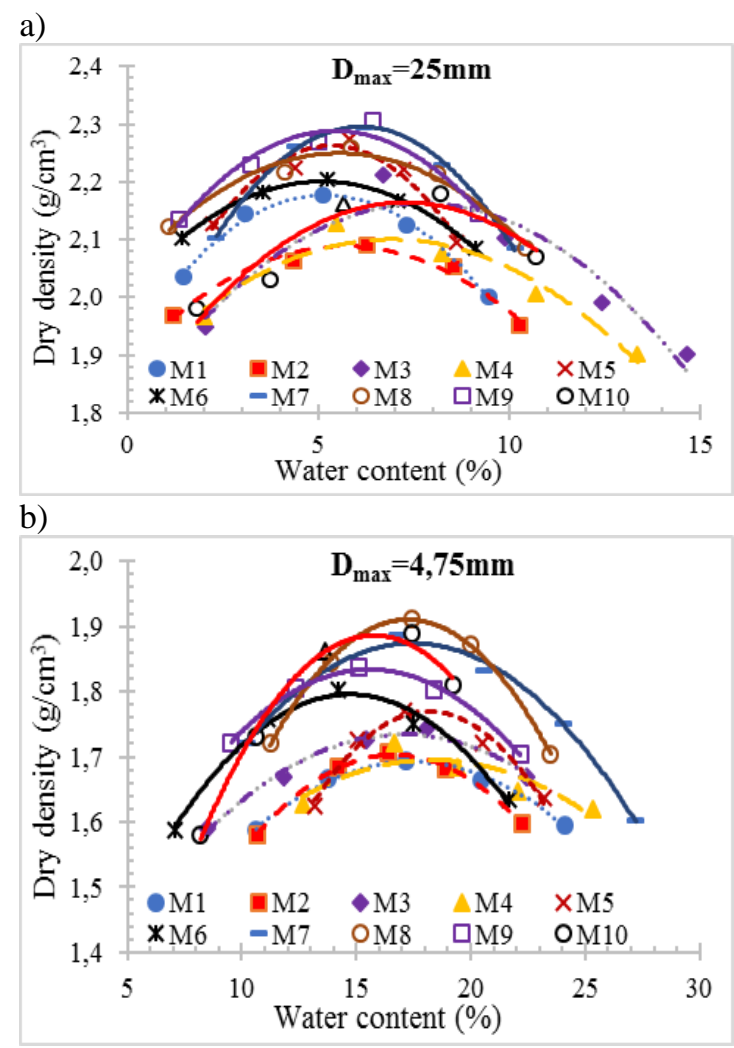

Fig.6 Compaction curves for RCAs (a) and RFAs (b)

\subsection{CBR Results}

The CBR results of RA samples after 96 hours of soaking are shown in Fig. 7 and Fig. 8. In which, Fig. 7a and Fig. 8a present the typical relationship between the penetration and compression pressure of the RCA and RFA M1 samples. Fig. 7b and Fig. 8b show the relationship between $\mathrm{CBR}$ values versus dry density. CBR at K98\% and other properties of RAs are summarised and compared with specifications in Table 3, Table 4.
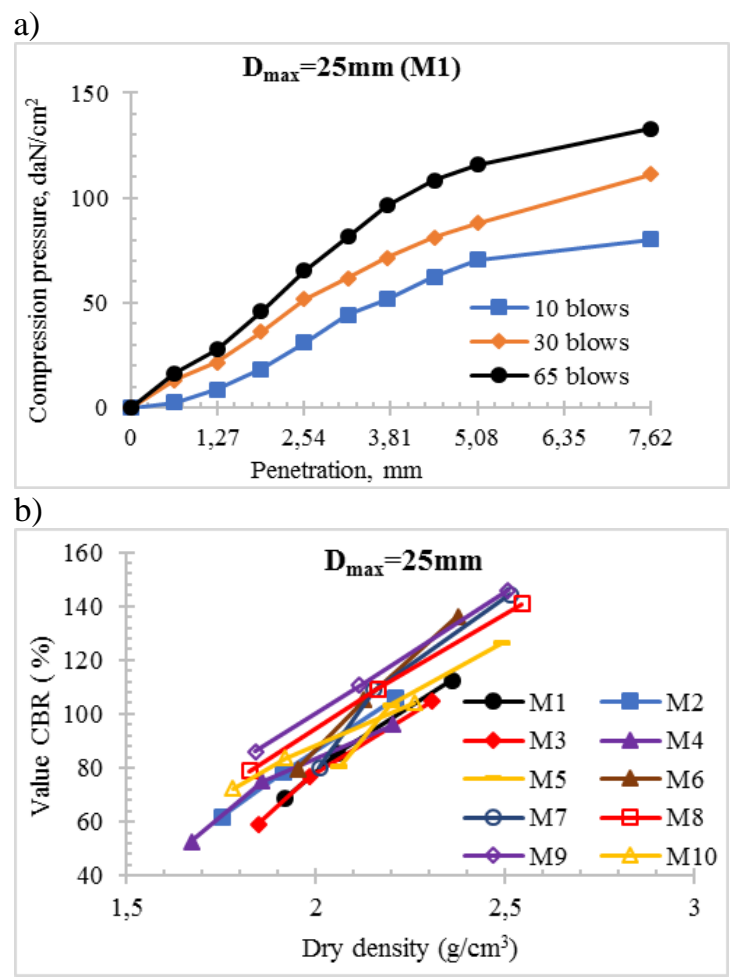

Fig.7 CBR test results of RCAs

The CBR value of RAs increased with increasing compacted energy and dry density (Fig. 7b and Fig. $8 b)$. The CBR value of RCAs is also 3-4 times higher than that of RFAs. CBR values vary widely from 89 to $123 \%$ for RCAs and from 33 to $44 \%$ for RFAs (Table 4). The main reason is that the compressive strength of the original sandstone varies from 30.1 to $83.0 \mathrm{MPa}$ (Fig. 3) and the unevenness of the particle composition, the percentage of the grain 0.075 to $0.425 \mathrm{~mm}$ is different. These grains are composed mainly of weathered clays, siltstone and fine ground sandstone particles, thus they are reducing the penetration resistance of RAs $[6,16]$. The CBR values of the RCA M2, M4 and M8 samples are quite low. This may be due to the small compaction energy level (10 blows/layer) and the high porosity of the RCA mixture leading to a decrease in the compressive resistance.

From Table 3 and Table 4 we could see the 
properties of RCAs and RFAs have satisfied the technical requirements as the materials for road foundations according to TCVN 8859: 2011 and TCVN 8857: 2011. Specifically, the RCA from M5, M6, M7, M8, M9 meet the requirements of Grade I macadam grading due to $\mathrm{CBR}$ value $\geq 100 \%$, the remaining RCAs from M1 to M4 meets the requirements of the grade aggregate type II according to TCVN 8859: 2011. However, the plasticity index $\left(\mathrm{I}_{\mathrm{P}}\right)$ and the $\mathrm{PP}$ index $(\mathrm{PP}=\mathrm{Ip} \times$ Passing $\%$ of $0.075 \mathrm{~mm})$ are quite high compare to the standard (M2, M3); although the Los Angeles abrasion (LA) and the elongation and flakiness content $\left(T_{d}\right)$ are still lower than those of the standards demand. The Los Angeles coefficient reflects the resistance to degradation of coarse aggregate by abrasion and impact in the Los Angeles machine. This is an important property to consider of aggregate usage for road foundations. In this study, M3, M5, M8, and M9 aggregates have higher fragmentation values than other sandstone aggregates (Table 3). This is probably due to the mineralogical characteristics of this sample which includes coarse particle size (Table 1) [9]. This means that we must be strictly controlled the compression ratio in field applications $[9,11]$.

a)

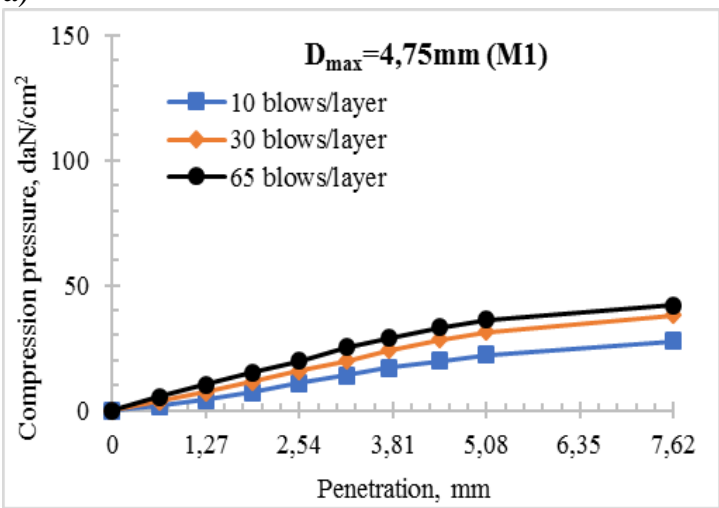

b)

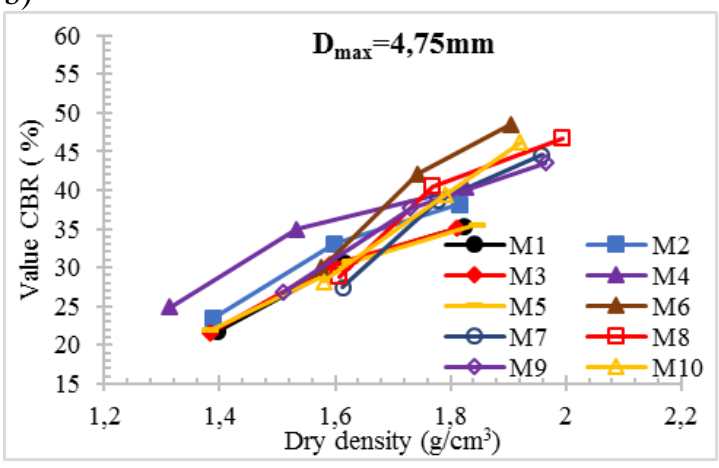

Fig.8 CBR test results of RFAs

For RFAs, it is possible to replace the soil and natural sand in the lower foundation layer grades A1 and A2; foundation layer type B1, B2 or surface layer type B1, B2, and reinforcing the sidewalk in the roadbed structures. However, both RAs have a high optimum moisture content and a high plasticity index (Table 3, Table 4); the passing $0.075 \mathrm{~mm}$ sieve content is higher than required (Table 4). Therefore, when applied in practice, it should be combined with the natural sand or macadam and needed to control low moisture content during construction to ensure good compaction.

Table 3 Summary of test results of RCAs compare to TCVN 8859:2011

\begin{tabular}{|c|c|c|c|c|c|c|c|c|}
\hline $\begin{array}{l}\text { Prop- } \\
\text { erties }\end{array}$ & $\begin{array}{l}\text { MDD, } \\
\mathrm{g} / \mathrm{cm}^{3}\end{array}$ & $\begin{array}{c}\text { OMC, } \\
\%\end{array}$ & $\begin{array}{c}\text { CBR } \\
\text { at } \\
\text { K98\% }\end{array}$ & $\begin{array}{c}\mathrm{W}_{\mathrm{L}} \\
\%\end{array}$ & $\begin{array}{l}\text { IP, } \\
\%\end{array}$ & PP, \% & $\begin{array}{c}\text { LA, } \\
\%\end{array}$ & $\begin{array}{l}\mathrm{T}_{\mathrm{d}} \\
\%\end{array}$ \\
\hline M1 & 2.176 & 5.1 & 93 & 23.4 & 10.3 & 20.6 & 29 & 2.5 \\
\hline M2 & 2.091 & 6.3 & 90 & 22.8 & 10.4 & 124.8 & 27 & 3.2 \\
\hline M3 & 2.212 & 6.7 & 92 & 24.7 & 11.3 & 50.8 & 30.5 & 3.5 \\
\hline M4 & 2.128 & 5.5 & 89 & 21.4 & 8.2 & 35.1 & 26.8 & 2.2 \\
\hline M5 & 2.273 & 5.8 & 105 & 20.8 & 7.2 & 33.1 & 30.4 & 4.1 \\
\hline M6 & 2.205 & 5.2 & 110 & 19.5 & 6.5 & 37.2 & 27.6 & 3.7 \\
\hline M7 & 2.295 & 6.2 & 120 & 21.6 & 6.7 & 6.0 & 28.8 & 4.1 \\
\hline M8 & 2.258 & 5.8 & 113 & 21.5 & 7.3 & 8.8 & 32.4 & 5.7 \\
\hline M9 & 2.307 & 6.4 & 123 & 20.6 & 8.2 & 12.3 & 30.6 & 4.0 \\
\hline M10 & 2.182 & 6.2 & 91 & 20.3 & 6.8 & 8.8 & 26.2 & 3.8 \\
\hline Type I* & - & - & $\geq 100$ & $\leq 25$ & $\leq 6$ & $\leq 45$ & $\leq 35$ & $\leq 18$ \\
\hline Type II* & - & - & - & $\leq 35$ & $\leq 6$ & $\leq 60$ & $\leq 40$ & $\leq 20$ \\
\hline
\end{tabular}

Table 4 Summary of test results of RFAs compare to TCVN 8857:2011

\begin{tabular}{ccccccc}
\hline $\begin{array}{c}\text { Prop- } \\
\text { erties }\end{array}$ & $\begin{array}{c}\text { MDD, } \\
\mathrm{g} / \mathrm{cm}^{3}\end{array}$ & $\begin{array}{c}\text { OMC, } \\
\%\end{array}$ & $\begin{array}{c}\text { CBR at } \\
\text { K98\% }\end{array}$ & $\begin{array}{c}\mathrm{W}_{\mathrm{L}}, \\
\%\end{array}$ & $\begin{array}{c}\mathrm{IP}, \\
\%\end{array}$ & $\begin{array}{c}\text { Passing } \% \\
\text { of } 0.075 \mathrm{~mm}\end{array}$ \\
\hline M1 & 1.695 & 17.2 & 33 & 25.6 & 11.2 & 8.6 \\
M2 & 1.706 & 16.4 & 35 & 26.5 & 9.7 & 2.5 \\
M3 & 1.744 & 18.1 & 33 & 28.1 & 12.7 & 6.2 \\
M4 & 1.720 & 16.6 & 38 & 28.4 & 11.5 & 8.7 \\
M5 & 1.770 & 17.1 & 33 & 28.1 & 13.4 & 3.2 \\
M6 & 1.802 & 14.2 & 43 & 28.4 & 11.6 & 4.7 \\
M7 & 1.886 & 16.8 & 41 & 32.3 & 14.9 & 3.6 \\
M8 & 1.912 & 17.4 & 44 & 30.7 & 12.3 & 4.0 \\
M9 & 1.837 & 15.1 & 40 & 29.5 & 11.7 & 3.6 \\
M10 & 1.823 & 16.8 & 39 & 29.6 & 12.5 & 3.3 \\
Lower A1* & - & - & $\geq 30$ & $\leq 35$ & $\leq 6$ & $\leq 0.67$ \\
Upper A2* & - & - & $\geq 80$ & $\leq 25$ & $\leq 6$ & $\leq 0.67$ \\
Lower A2* & - & - & $\geq 30$ & $\leq 35$ & $\leq 6$ & $\leq 0.67$ \\
Subgrade & - & - & $\geq 30$ & $\leq 35$ & $\leq 12$ & - \\
B1, B2* & - & & & & \\
Surface & - & - & $\geq 30$ & $\leq 35$ & $9-12$ & $\leq 0.67$ \\
B1, B2* & - & & \\
\hline Note: “*” Requirements by TCVN 8857: 2011; \\
“- “ indicates that there is no relevant standard value
\end{tabular}




\section{CONCLUSION}

The results show that it is possible to recycle the coal mining waste from the carboniferous region of Quang Ninh to obtain recycled aggregates that use in road construction. Utilization of mine waste rocks in pavement layers will not only help in sustainable and greener construction development but also present technical viability and environmental benefits due to the demand for natural aggregate deposits which can be minimized and almost all of the coal mining wastes can be used and help to reduce their volume in coal waste stockpiles. We believe that this procedure can be applied to minimize the environmental problems posed by coal production as in Vietnam.

The recycled coarse aggregates with $D_{\max }=25 \mathrm{~mm}$ from coal mining wastes could have good particle distribution, optimum moisture content and maximum dry density respectively reach $5.1-6.7 \%$ và $2.091-2.307 \mathrm{~g} / \mathrm{cm}^{3}$, as well as the excellent CBR values in the range of $89-123 \%$. These values are comparable to compacted natural granular fills in the base and subbase layers used in the road construction by TCVN 8859:2011.

The recycled fine aggregates with $D_{\max }=4.75 \mathrm{~mm}$ from coal mining wastes have similar properties of natural sand and soils with maximum dry density from 1.695 to1.912 $\mathrm{g} / \mathrm{cm}^{3}$ and CBR value in the range of $33-44 \%$, in contrast, their optimum moisture content is quite high from 14.2 to $18.1 \%$. The properties are similar to those of the natural sand for backfill, so it is possible to use this material as the backfill material in traffic construction projects.

Trace metals and sulfur may be present in coal mining wastes that may result in leachate water with high $\mathrm{pH}$ and corrosive characteristics for many years after its application in construction. So that the concentration of heavy metals and hazardous compounds extracted from recycled aggregates should be tested before its application to road subgrade, base and subbase layers in the follow-up study.

\section{ACKNOWLEDGEMENTS}

This research was funded as a project (code TÐ 144-17) of the Ministry of Construction (MOC) Vietnam. The authors sincerely thank the financial support of the National University of Civil Engineering (NUCE); Thien Nam Joint Stock Company prepared materials for this study.

\section{REFERENCES}

[1] Eurostat, Energy, Transport and Environment statistics- 2020 edition, Office of the European
Union, 2020, pp. 109-118.

[2] EPA U.S., Hazardous Waste. Report on the Environment. https://www.epa.gov/roe/, 2020, pp. 1-6.

[3] Bin H.L., and Zhenling L., Recycling utilization patterns of coal mining waste in China. Resources, Conservation and Recycling, Volume 54, Issue 12, 2010, pp. 1331-1340.

[4] Burdzieva O.G., Alborov I.D., Tedeeva F.G., Makiev V.D., Glazov A.P, Mining caused pollution of the natural landscape. International Journal of GEOMATE, Vol.15, Issue 51, 2018 pp. 195-200.

[5] Gayanaa B.C., and Chandar K.R., Sustainable use of mine waste and tailings with suitable admixture as aggregates in concrete pavementsA review. Advances in Concrete Construction, Vol. 6, No.3, 2018, pp. 221-243.

[6] Indraratna B., Gasson I., and Chowdhu A.N.D.R.N., Utilization of compacted coal tailings as a structural fill. Canada GEOTECH Journal Vol. 31, 1994, pp. 614-623.

[7] Santos C. R., Tubino R. M. C., and Schneider I. A. H., Mineral processing and characterization of coal waste to be used as fine aggregates for concrete paving blocks. IBRACON Structures and Materials Journal, Volume 8, Number 1, 2015, pp. 14-24.

[8] David H., Gary W.S., Jerry G.R., and Robert C.D., Road base construction utilizing coal waste materials. Research Report UKTRP-8715, 1987, pp. 1-16.

[9] Jiang H., Characterisation of coal-mine waste in solid backfill mining in China. Mining Technology Vol. 124, Issue 1, 2015, pp. 56-63.

[10] Yilmaz M., and Tug rul A., The effects of different sandstone aggregates on concrete strength. Const. Build. Mat., Vol. 35, 2012, pp. 294-303.

[11] Karfakis M. G., Bowman C. H., and Topuz E., Characterization of coal-mine refuse as backfilling material. Geotech Geol Eng 14, 129-150, Vol. 14, 1996, pp. 129-150.

[12] Thai H.N., Akira K., Nguyen H.G., Nguyen T.D., Tong T.K., Nguyen V.T., Uchimura T., Maki T., and Kawamoto K., Effects of particle size and type of aggregate on mechanical properties and environmental safety of unbound road base and subbase materials: a literature review. International Journal of GEOMATE, Vol.20, Issue 78, 2021, pp. 148-157.

[13] Decision No. 1469/QD-TTG dated 22/8/2014, Approving the Master Plan on development of Vietnam's construction materials by 2020 and 
orientation to 2030. The Prime Minister, 2014, pp. 13-20.

[14] Pham V.B., Workshop proceedings of The National Science and Technology Workshop on Crushed Sand to replace Natural sandEnvironmentally friendly materials; Quang Ninh, June 8, 2018, pp. 13-20.

[15]Tong T.K., Research to complete equipment and technology for manufacturing crushed sand from recovered sandstone at coal mining waste dumps for use in construction applications. Final report of the Ministry of Construction's project code No. 144-17, 2019, pp. 1-272.

[16] Ministry of Natural Resources and Environment, National environment report- solid waste, 2017, pp. 1-160.

[17]Decision No. 1160/QD-UBND dated 06/06/2014, Approving the planning of exploration, exploitation, and use of minerals and small scattered minerals for common construction materials production in Quang Ninh province until 2020, vision to 2030. The People's Committee of Quang Ninh province, 2014, pp. 1-32.

[18] TCVN 6706, Hazardous wastes- Classification. Vietnam national standard, 2009, pp. 1-19.

[19] National technical regulations on safety in the exploitation of open-cast mines. Circular No. 20/2009/TT-BCT of the Ministry of Industry and Trade, 2009, pp. 1-88.

[20]TCVN 7572, Aggregates for concrete and mortar - Test methods. Vietnam national standard, 2006, pp. 1-90.

[21]TCVN 8859, Graded Aggregate Bases and Subbases Pavement - Specification for Construction and Acceptance. Vietnam national standard, 2011, pp. 1-17.
[22] TCVN 8857, Natural Aggregate for Road Pavement Layers Specification for Material, Construction, and Acceptance. Vietnam national standard, 2011, pp. 1-14.

[23] TCVN 4198, Soils - Laboratory methods for particle-size distribution analysis. Vietnam national standard, 2014, pp. 1-28.

[24] ASTM D6913/D6913M, Standard Test Methods for Particle-Size Distribution (Gradation) of Soils Using Sieve Analysis, ASTM International, 2017, pp. 1-35.

[25] AASHTO T99, Standard Method of Test for Moisture-Density Relations of Soils Using a 2.5-kg (5.5-lb) Rammer and a 305-mm (12-in.) Drop. American Association of State Highway and Transportation Officials, 2019, pp. 1-14.

[26] AASHTO T180, Standard Method of Test for Moisture-Density Relations of Soils Using a 4.54-kg (10-lb) Rammer and a 457-mm (18-in.) Drop. American Association of State Highway and Transportation Officials, 2020, pp. 1-14.

[27] AASHTO T193, Standard Method of Test for The California Bearing Ratio. American Association of State Highway and Transportation Officials, 2013, pp. 1-12.

[28] TCVN 4197, Soils - Laboratory methods for determination of plastic limit and liquid limit. Vietnam national standard, 2012, pp. 13-20.

[29] AASHTO T90, Standard Method of Test for Determining the Plastic Limit and Plasticity Index of Soils. American Association of State Highway and Transportation Officials, 2020, pp. 1-6.

Copyright (C) Int. J. of GEOMATE. All rights reserved, including the making of copies unless permission is obtained from the copyright proprietors. 